\title{
A NEUROMARKETING STUDY ON MONGOLIAN CONSUMERS' BUYING DECISION PROCESS
}

Boldbaatar G.

Business School of the University of Humanities, Mongolia corresponding author: e-mail: ezo_boldbaatar@yahoo.com

\begin{abstract}
There has been almost 20 years since science of marketing has developed in Mongolia and there has been significant progress in acquiring and using it. Business companies'leadership have become aware of the importance of this science and see marketing as business philosophy and understand that analyzing the market, business environment and conditions by consumers is the key to success.

Today's society demands from marketing professionals' delicacy and taking into account consumers' needs and creating new needs and new means of consumption. Main purpose of business entities is to be aware of consumer needs, to establish its position on the market and to be successful. In order to provide consumers with the best products and keep them at the center of their attention it is important to establish optimal ratio of marketing factors that would most efficiently influence consumers with different behaviors.
\end{abstract}

Keywords: Neuromarketing, consumers, business companies, market, consumer needs, products, buying decision, neuroscience;

\section{INTRODUCTION}

In recent years new research tendencies have emerged that reveal the ways psychological factors such emotions, imagination, feeling influence decision making of consumers in the process of buying goods. One of the fields of the research is neuromarketing.

Objectives of the study

- To investigate different theories about neuromarketing and their scientific contributions made in the recent years.

- To evaluate through some neuromarketing research the process of Mongolian consumers' buying decision

- To evaluate the benefits and the ways of using neuromarketing application techniques in marketing in Mongolia

\section{MATERIAL AND METHODS}

Literature review: marketing books, research papers from journals with referee, journal articles, academic papers, and materials available in the internet.

Theoretical background: academic papers and articles on human physiology, biology and neuromarketing written by foreign researchers

Interviews: surveys on over 250 people, based on the observation of buyology and field trips involving over 1500 people. 
Collaboration with specialists, experts and professionals in neuroscience. Along with a business standpoint. The organizations involved:

- The "Chuluunaa" neuroclinic.

- Mongolian marketing research institute

Validation of the effectiveness and efficiency of neuromarketing.

- Personal interviews (papers)

- Interviews through the internet

The structure of the study:

Part 1. Background of the neuromarketing concept

Part 2. Introduction to the neuroscience

Part 3.Techniques used to attract consumers and stimulate them through marketing and advertising

Part 4. Consumer behavior and their attitude reactions

\section{Neuromarketing concept}

Where is the limit when decoding the most attractive color, packaging, jingle or shape for the consumers? Are they able to know how and what consumers think when they buy their products? Is it possible to "read" the mind of the consumer, know their motivations, their desires and their purchase decisions? Neuromarketing aims to reveal the answer to all these questions.

Neuromarketing is an integration of marketing and neuroscience which studies the use of neuroscience and its findings in marketing science, including the psychological process of buying, the factors that affect the process and decision making process. Consumer's buying decision is related to the brain activity; therefore, the businesses should study neuromarketing in order to make consumers buy more.

\section{How does our brain work?}

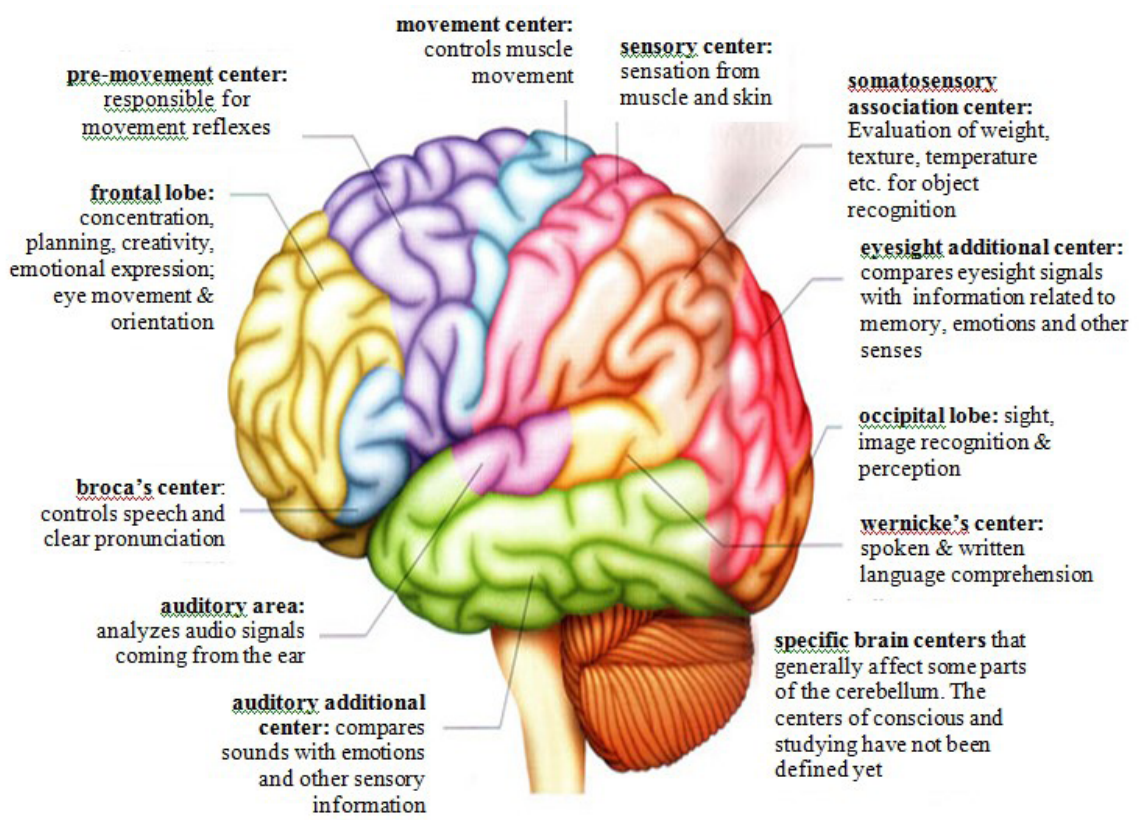

Graph 1. In the graph below there are shown the main brain areas in which the stimuli are originated, and also how the nervous system process is developed

Source: Kim Min Ju (2008) "Neuromarketing" 
Left hemisphere functions

Abstract thinking

Oriented to details sees things in parts analysis

smart

mathematical thinking

based on the consequences

real desire

realizing things

be close to reality

knowledge \& five senses

past and present

words \& speech

cognition, proof

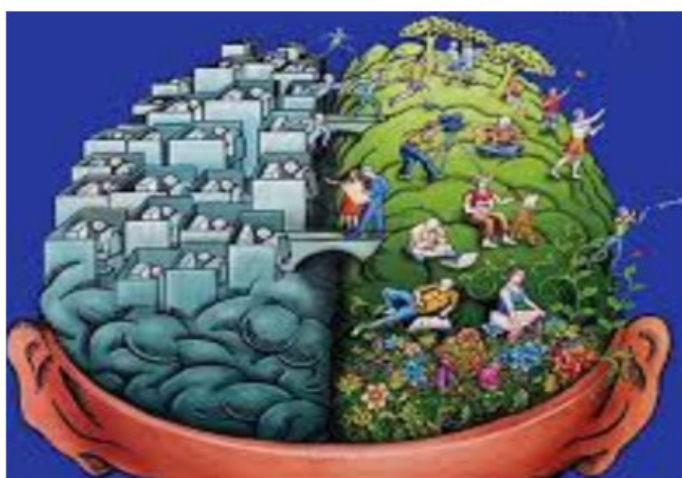

Right hemisphere functions

Creative thinking oriented to general things sees things as a whole prediction intuition philosophical thinking summarising subjectivity using one's feeling imagining expression, signs present and future hope and hypothesis factual evaluation

Figure1. The brain is divided into the two equal parts.

Source: Graf, P. (2002): Lifespan Development of Human Memory. Cambridge: MIT Press

The left brain is associated with logical thinking and it is responsible for speaking, numbers, sequence and analysis. The right brain is associated with creative thinking and it is responsible for space, colors, music rhythm, imagination and description. Also this part is called 'scientifical'. However, in most human brain processes related to conscious and thinking both parts of brain are involved.

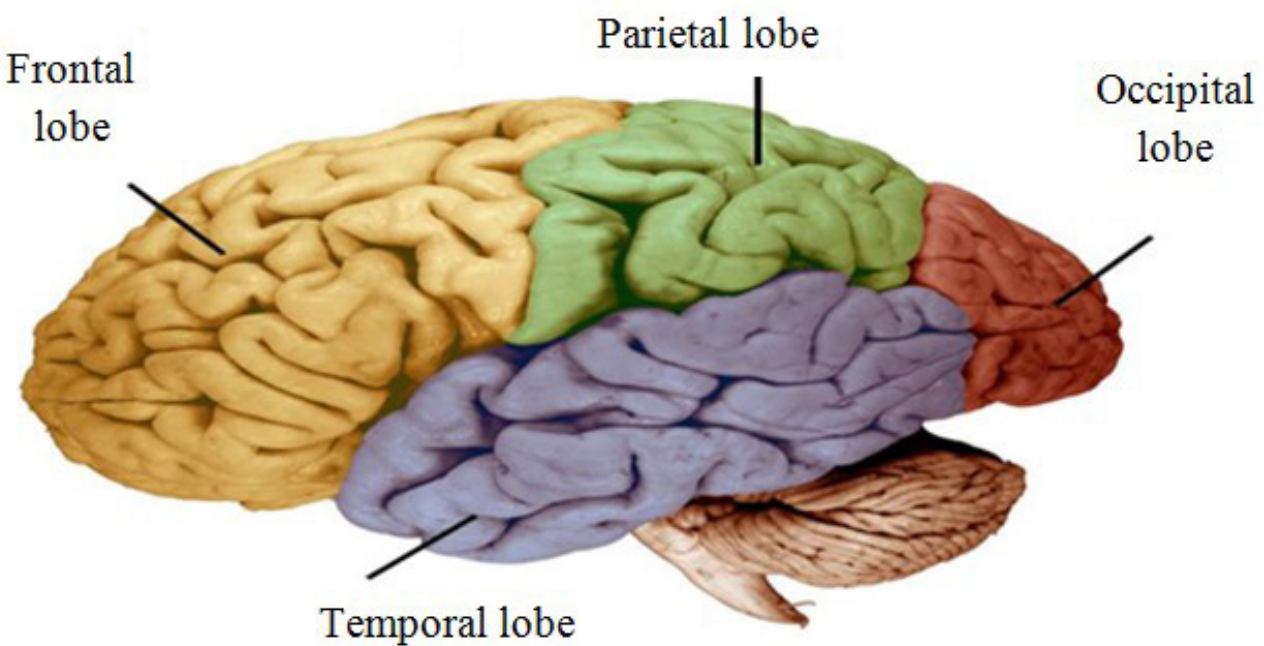

Figure 2. Brain formed by four main lobes (Frontal lobe, Parietal lobe, Occipital lobe, Temporal lobe). Source: Miller, B.l. et al. (1999): The Human Frontal lobes. New York: guilford Publications

These lobes are responsible for processing different stimuli and thought.

Synapses: specialized intercellular junction between neurons. It carries out the transmission of nerve impulses and download chemical that causes an electric current transmitted along the axon by transmitters, to other neurons, thus triggering a reaction to a stimulus. 


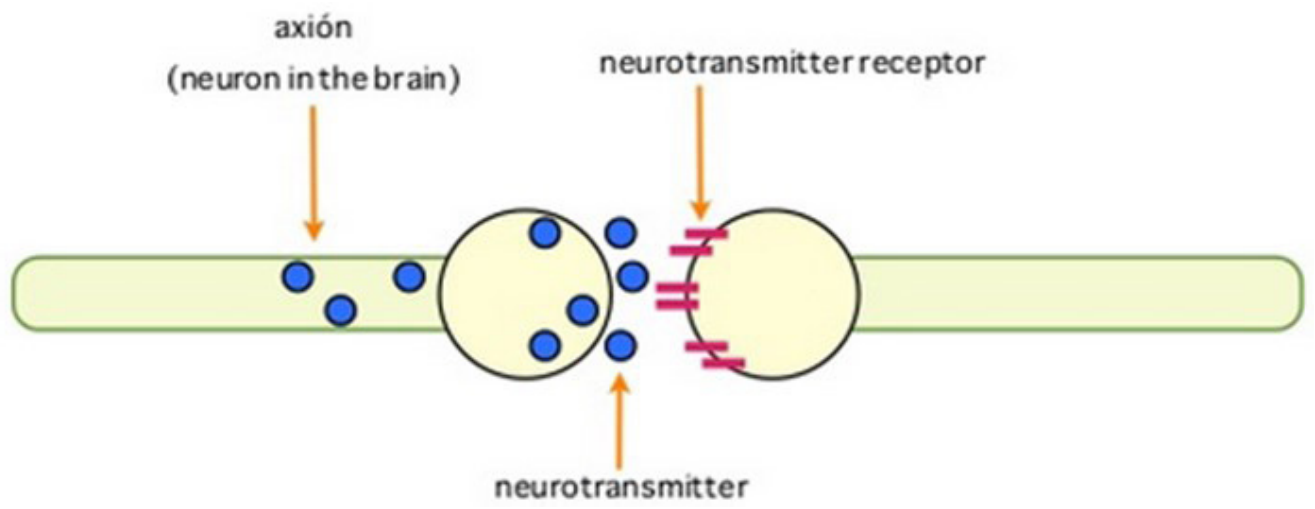

Graph 2. specialized intercellular junction between neurons

Source: Hausel, H.G. (2002/2003): Think Limbic! Planegg: Haufe Verlag

Study intended to understand consumer behavior

"Marketing and surrounding environment affect consumer mind whereas psychological process is interrelated to certain characteristics resulted in buying decision and decision making. The purpose of marketing is to understand what happens in the consumer mind between the final buying decision and the stimuli of buying".

Below we can see the changes happening in consumer's mind during this process.

Sensory system:

- Exposure

- Attention

- Interpretation

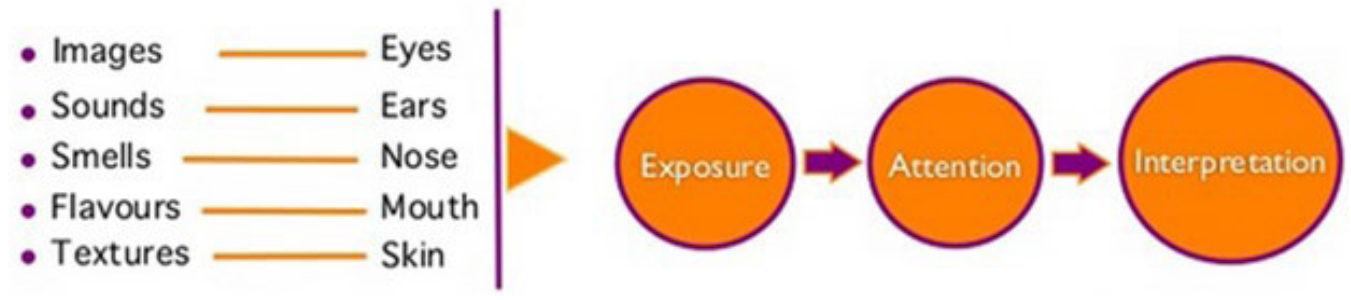

Graph 3.Sensory system

Source: Hausel, H.G. (2002/2003): Think Limbic! Planegg: Haufe Verlag

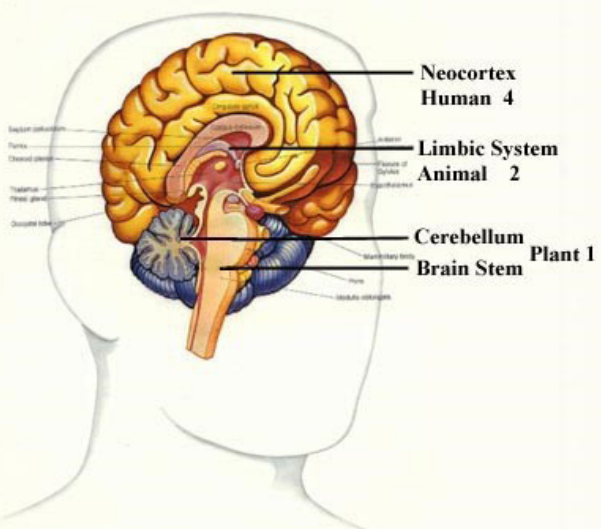

Figure 3. General structure of brain Source: Kim Min Ju (2008) "Neuromarketing" 
Consumer goods have their value when they activate the feelings and reasoning in consumer's brain. The more this system is intervened, the more value the goods have.

In order to understand the buying decision process let us see a detailed brain picture.

Brain generally is divided into the three parts. The lowest part is called brain stem which is the oldest one in origin. Above it there are other parts: cerebellum, diencephalons and cerebrum. Neocortex is the most important component of the cerebrum which originated last and is the biggest in size.

Feelings or emotions are in charge of decision making because the human brain is ruled by one's emotions.

The reasoning and emotional system is located between the brain stem and diencephalons. The latest researches have proved that the cerebrum is a limbic system which works in accordance with reasoning rules. [12]

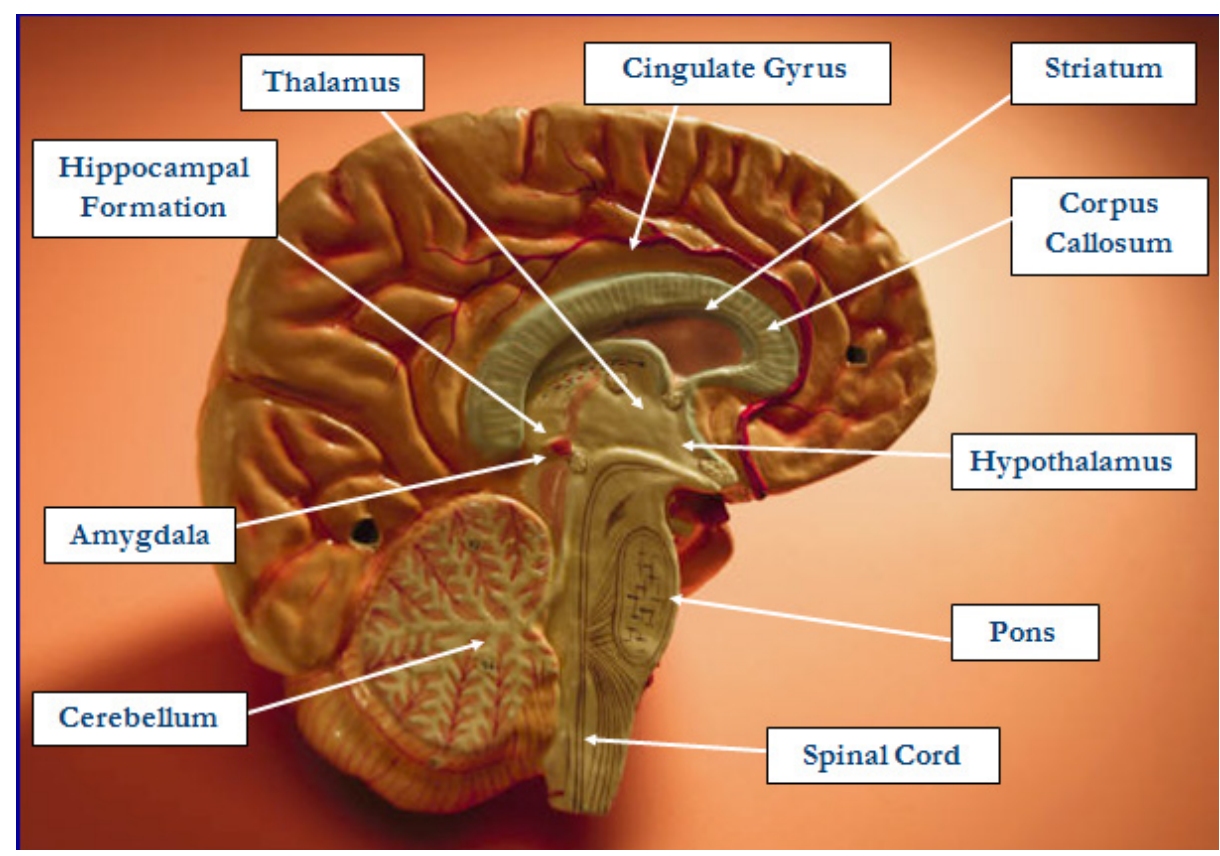

Figure 4. The limbic system is responsible for our feelings, emotions and desires.

Source: Hans- Georg Hausel “ Brain View”, 2008

Neuromarketing studies was first done by the Harvard university professor Herry Zaltman in the XIX century whereas German neuropsychologist Hans-Georg has developed the "Limbic Map" which has become the means of increasing sales of business companies and individuals and rational strategic planning.
There are three different reasoning and feeling systems in human brain that totally manage one's life. They are called 'great threes' and they are as follows:

- triggering system

- managing system and

- balancing system 


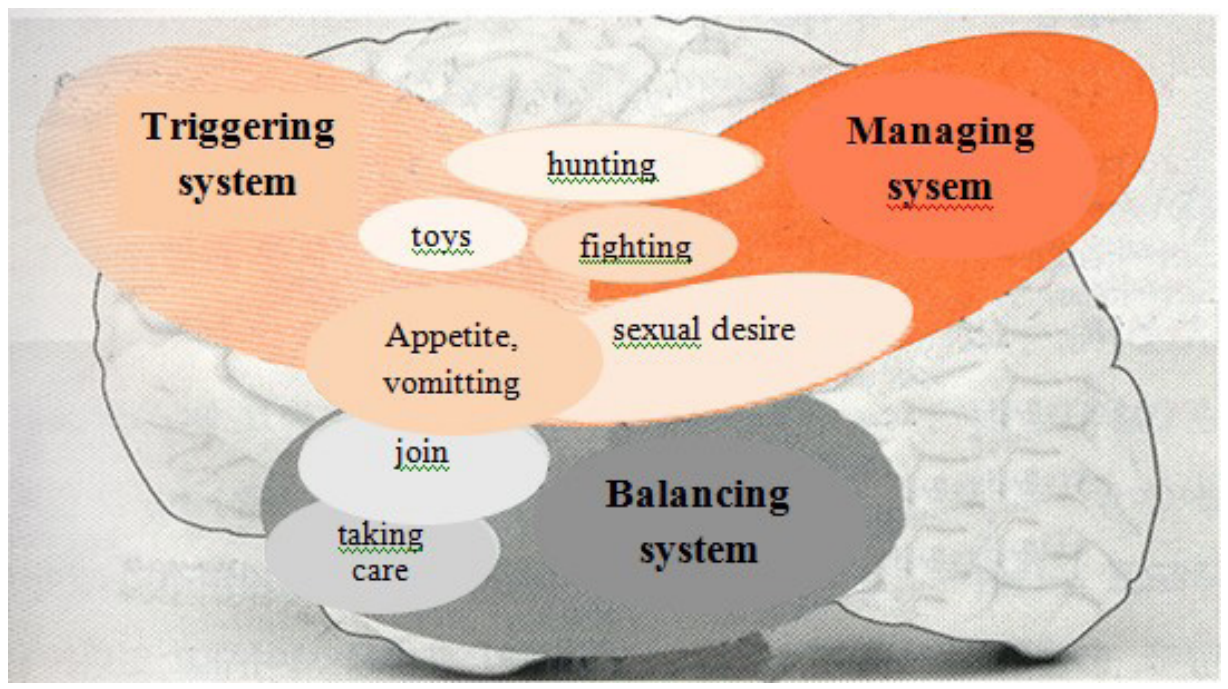

Figure 5. "great threes"

Source: Kim Min Ju (2008) "Neuromarketing"

In the human evolution process except of these three more different modules have developed.These modules exist within or between the abovementioned three systems. The modules are responsible for better adapting people to their environment. They are as follows:

- reconciliation module

- module of taking care

\section{RESULTS}

Findings of our study: Recent researches in this field show that percentage of emotions and feeling that affect buying decision is 70$80 \%$, that is done unconsciously. Conscious evaluation exists, though. It is represented by $20-30 \%$ but it cannot be as free as we imagine.

In accordance with 'Limbic map' we can classify consumers into 7 types based on the consumer's extent of feeling. Classification of Mongolian consumers according to this map showed the following:

\section{Relation of Children and Temper}

Child(ren) can affect their parents' moods or temper. Often their enthusiasm for success and risk can decrease and caring module can have a big influence on their brain activity.
- $\quad$ toys \& play module

- hunting module

- fighting module

- appetite/vomiting module

- sexual desire module

Behind the each module in 'three great"there are hidden high level orderly processes which involve all the brain parts and a lot of neurons.[18]

When a child is born there are changes in his/her father's hormone system. The volume of testosterones decreases and the caring module hormone called 'prolactic' increases every time the father has a contact with his child.

Men and women's brain

The brain researchers have found a lot of differences in men and women's brains.

The part of the brain that connects right and left hemispheres is thicker in women than in men.

The size of the control/nerve center in the hypothalamus in men are twice bigger than in women's brain. 


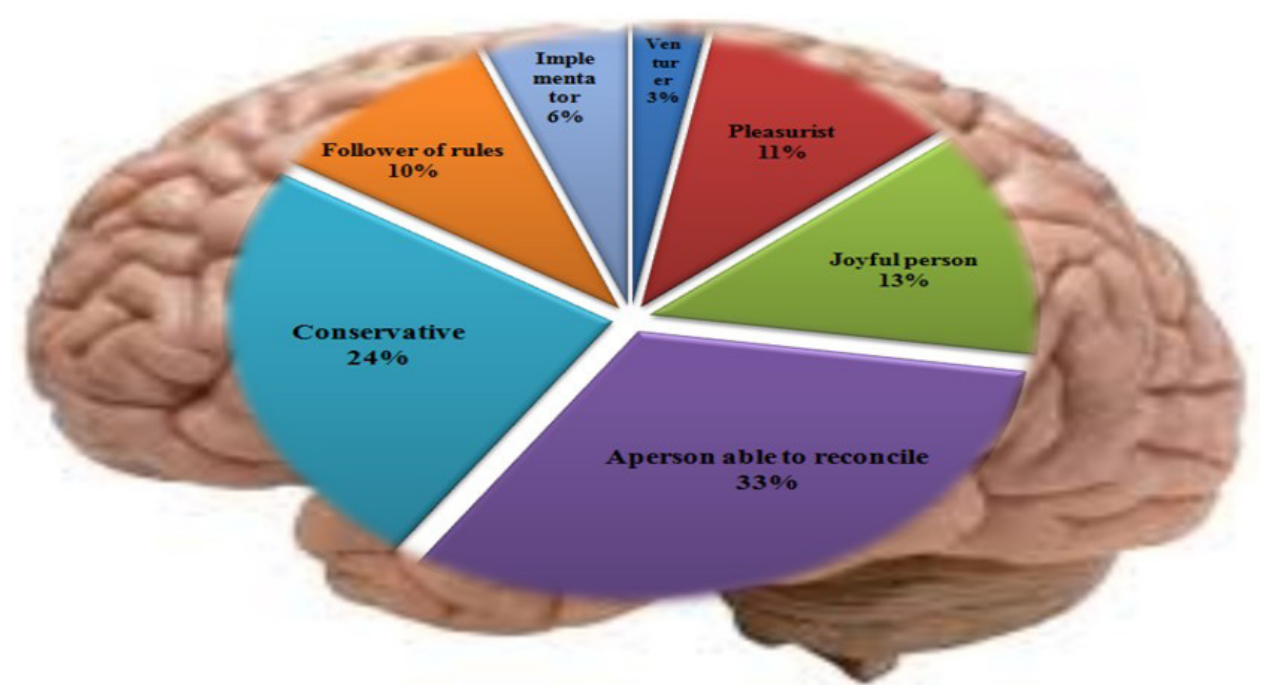

Figure 6. Limbic map' classification of Mongolian consumers

Source: results of research

The part of the brain in Limbic system that controls caring and socializing functions are twice bigger in women than in men.

Men's brain functions are more differentiated than those of women.

Brain structure is different, too. Women's brain has more brown cells/tissues while men's one has more white cells/tissues.

Table 1. Level of interest towards goods/products by men and women

\begin{tabular}{|l|c|c|}
\hline \multicolumn{1}{|c|}{ Products /goods of interest } & males & females \\
\hline Sport products & 160 & 90 \\
\hline HiFi stereo instruments & 170 & 80 \\
\hline Vehicles & 185 & 65 \\
\hline Home appliances and interior design products & 60 & 190 \\
\hline Foods & 75 & 175 \\
\hline Cleaning products \& cosmetics & 67 & 183 \\
\hline
\end{tabular}

Consumers spend a lot of money when they buy products that trigger their emotions.

Table 2. Clothes and age

\begin{tabular}{|l|c|c|c|c|}
\hline \multicolumn{1}{|c|}{ Fashion style /age } & $\mathbf{1 4 - 2 9}$ & $\mathbf{3 0 - 4 4}$ & $\mathbf{4 5 - 5 9}$ & Above 60 \\
\hline Old-fashioned clothes & $24 \%$ & $41 \%$ & $50 \%$ & $60 \%$ \\
\hline Clothes comfortable for exercising & $57 \%$ & $54 \%$ & $45 \%$ & $25 \%$ \\
\hline Clothes of latest trend & $53 \%$ & $41 \%$ & $33 \%$ & $16 \%$ \\
\hline Plain clothes & $13 \%$ & $24 \%$ & $30 \%$ & $45 \%$ \\
\hline Elegant colorful clothes & $25 \%$ & $19 \%$ & $17 \%$ & $12 \%$ \\
\hline
\end{tabular}

Style of clothes is usually regulated by control and triggering system of the brain.

\section{Influence of music on buying}

We have studied the way different music affects consumer's buying decision by observing them on CCTV in wholesale trade center. The results were as follows: 


\begin{tabular}{lr}
\hline \multicolumn{2}{c}{ Regression Statistics } \\
\hline Multiple R & 0.049495607 \\
R Square & 0.002449815 \\
Adjusted R & \\
Square & -0.05296964 \\
Standard Error & 0.05873715 \\
Observations & 20 \\
\hline
\end{tabular}

\begin{tabular}{lrcccc} 
ANOVA & \multicolumn{6}{c}{ Significance } \\
& \multicolumn{1}{c}{$d f$} & \multicolumn{1}{c}{ SS } & MS & $F$ & $F$ \\
\hline Regression & 1 & 14259946.47 & 14259946.47 & 0.044204967 & 0.835834327 \\
Residual & 18 & 5806565534 & 322586974.1 & & \\
Total & 19 & 5820825480 & & & \\
\hline
\end{tabular}

\begin{tabular}{lccccrc}
\hline & Coefficients & $\begin{array}{c}\text { Standard } \\
\text { Error }\end{array}$ & t Stat & P-value & Lower 95\% & Upper 95\% \\
\hline $\begin{array}{l}\text { Intercept } \\
\mathrm{X}\end{array}$ & 14806.42105 & 8343.313092 & 1.774645262 & 0.092870596 & 2722.229283 & 32335.07139 \\
Variable 1 & 146.4360902 & 696.4863201 & 0.210249772 & 0.8358343327 & 1316.827368 & 1609.699549 \\
\hline
\end{tabular}

\begin{tabular}{rr}
\hline $\begin{array}{r}\text { Lower } \\
95.0 \%\end{array}$ & $\begin{array}{c}\text { Upper } \\
95.0 \%\end{array}$ \\
\hline $\begin{array}{r}\text { - } \\
2722.229283\end{array}$ & 32335.07139 \\
- & \\
1316.827368 & 1609.699549 \\
\hline
\end{tabular}

F-Test Two-Sample for Variances

\begin{tabular}{lrr}
\hline & Variable 1 & Variable 2 \\
\hline Mean & 48846.5 & 65190.5 \\
Variance & 951621318.7 & 1224349437 \\
Observations & 20 & 20 \\
df & 19 & 19 \\
F & 0.777246504 & \\
P $F<=$ f) one-tail & 0.294138184 & \\
F Critical one-tail & 0.461201089 & \\
\hline
\end{tabular}

We observed that sales in the center has increased by 16344 Mongolian tugrucs or 33\% and we concluded that $4 \%$ of sales increase is due to music played at the trade center and other indexes are the result of other factors. The music increases the sale on average for 146 tugrucs which is $\mathrm{F}=0.77$ 
Table 3. Influence of some factors on make buying decision

ANOVA $^{\mathrm{b}}$

\begin{tabular}{|c|c|c|c|c|c|c|}
\hline \multicolumn{2}{|c|}{ Model } & Sum of Squares & df & Mean Square & F & Sig. \\
\hline \multirow{3}{*}{1} & Regression & 19.451 & 7 & 2.779 & 1.775 & $.103^{\text {a }}$ \\
\cline { 2 - 7 } & Residual & 128.337 & 82 & 1.565 & & \\
\cline { 2 - 7 } & Total & 147.789 & 89 & & & \\
\hline
\end{tabular}

a. Predictors: (Constant), Buy based on brand name, buy taking into account the necessary to satisfy the consumption, Fashion, design, exotic kheentsert to buy based on the emotional, appearance and beautiful drawn into in buy, Regard product casting and technology used in the production of goods to buy, Buy based on the quality

b. Dependent Variable: make buying decision

Table 4. Coefficients ${ }^{a}$

\begin{tabular}{|c|c|c|c|c|c|c|}
\hline & \multirow{2}{*}{ Model } & \multicolumn{2}{|c|}{$\begin{array}{l}\text { Unstandardized } \\
\text { Coefficients }\end{array}$} & \multirow{2}{*}{$\begin{array}{c}\text { Standardized } \\
\text { Coefficients } \\
\text { Beta }\end{array}$} & \multirow{2}{*}{$\mathrm{t}$} & \multirow{2}{*}{ Sig. } \\
\hline & & $\mathrm{B}$ & $\begin{array}{l}\text { Std. } \\
\text { Error }\end{array}$ & & & \\
\hline \multirow{7}{*}{1} & (Constant) & .389 & 1.906 & & .204 & .003 \\
\hline & $\begin{array}{l}\text { Fashion, design, exotic kheentsert } \\
\text { to buy based on the emotional }\end{array}$ & -.101 & .282 & -.039 & -.359 & .721 \\
\hline & $\begin{array}{l}\text { appearance and beautiful drawn } \\
\text { into in buy }\end{array}$ & .089 & .359 & .027 & .249 & .804 \\
\hline & $\begin{array}{l}\text { Buy taking into account } \\
\text { the necessary to satisfy the } \\
\text { consumption }\end{array}$ & .013 & .298 & .005 & .042 & .966 \\
\hline & Buy based on the quality & .632 & .291 & .238 & 2.171 & .033 \\
\hline & $\begin{array}{l}\text { Regard product casting and } \\
\text { technology used in the production } \\
\text { of goods to buy }\end{array}$ & .983 & .522 & .205 & 1.882 & .063 \\
\hline & Buy based on brand name & -.142 & .134 & -.116 & -1.065 & .290 \\
\hline
\end{tabular}

a. Dependent Variable: make buying decision

The strongest factor affecting to customers buying decisions is the Regard product casting and technology used in the production of goods to buy (0.98), and Buy based on the quality $(0.63)$.

In studying consumers' brain activity we focus on combination of the latest techniques of psychology and neuroscience research with neuromarketing in analysis of consumers' responses to products, brands and commercial ads. The results show that marketers need to differentiate unusual waves in consumers' brain while using brain science technology and methods.

\section{Systems and techniques to measure the brain activity}

- fMRI - functional magnetic resonance imaging

- QEEG - electroencephalography

- Eye tracking

Essential methods of nueromarketing are presented below:

fMRI - functional magnetic resonance imaging. The method has developed since the beginning of the 1990s. The equipment allows to see the detailed observation of activated zones in the brain in defining psychological responses to trigger. 3D encoding: activated zones are multicolored. The method initially has been used to reveal headaches, paralysis and convulsions.

QEEG - electroencephalography. Issues defining cognitive messages and psychological responses [on the subconscious level] give opportunities to make valuable, deep and accurate analysis about consumers' internal decision making process".

Eye tracking. Application of these methods are only in the beginning stage in Mongolia. In other words, the level of applying these methods show the following result: fMRI is only $1 \%$, QEEG- 3\% and Eye Tracking - $0.3 \%$. 
Furthermore, fMRI and QEEG are used in cooperation with clinic and medical specialists in only academic research whereas Eye
Tracking has been used by MCCG marketing Research Company in Mongolia since 2015. As we can see in Tab. 3

\section{CONCLUSION}

Combining nueuromarketing science and marketing

FMRI, QEEG methods can reveal performance failure in the cerebrum which is responsible for buying decision making.

Sudden decision of buying (regulated by Limbic system) is based on buyer's mood

whereas balanced buying decision is processed in the brain cortex in front lobe of the brain. Inappropriate purchase or sale is connected with nervous system currents.

Potential influence of neuromarketing promotion campaign

Poster/notice board:

- Location

- Period of time

Web advertising:

- Period of time

- Content

Sponsorship:

- Holidays

- Event

Potential influence of neuromarketing advertising model

Poster/notice board:

- Size

- Slogan/message

- Colour harmony

- Sportsman

TV advertising

- Balance of information/entertainment

- Length

- Main product

- Colour harmony

- Image

- Music

- Taste

- Smell

- Color

- Health/fasion tendency

- Defining a new target group

Potential influence of neuromarketing - product packaging/model

- Logo

- Packaging material
TV/radio:

- Channel/station

- Broadcasting time

Free of charge/additional bonus

- Location

- Choice of the product
Promotion through radio:

- Balance of information/entertainment

- Length

- Voice

- Music
Potential influence of neuromarketing of product development

- Colour

- Prepagkage size 
- Limited printing

- Smell

- Goods' counter/sand

Potential influence of neuromarketing in distribution

- Special offer

- Product groups

- Music

- Smell

- Sufficiency

- General atmosphere

Technological limitations:

Neuromarketing between the reality and promotion

- $\quad$ People involved in neuromarketing experiments express resentment about participating in brain tests.

- $\quad$ Some participants feel cautious and anticipated due to noises and closeness of experimenting equipment.

- The results of the experiments are not always accurate due to worry and uncomforting feeling of the participants.

- $\quad$ Big and inflexible equipment (artificial environment)

- $\quad$ Lack of medical observation during the experiments

- Time and money constraints do not allow to conduct extensive observation and study

General limitations:

- $\quad$ Accurate measurement of brain activity is limited

- $\quad$ Some emotions and feelings cannot be clearly distinguished

- $\quad$ Analysis of obtained data is not clear, somewhat puzzling

- Neuromarketing do not express future.

1. Consumer behavior cannot be constituted in laboratory conditions

2. Experiment time and expenses prevent participants from taking part in many tests

3. The brain activity cannot be measured.

"Marketing leaders point out the significance of the neuroscience in developing best practices and models of product realization. [...] Marketing consulting companies use smartly fMRI in creating ads aimed at finding a buying button in man's brain".

This gives significant additional opportunity for marketers to understand today's consumer behavior, and the neuroscience methods of studying consumers lead to changing the basics of today's marketing principles.

It will introduce the perspective of potential subconscious to update and extend the quantative research. This study might be the first method that used the opportunity to include habitat in quantative research. We do not dismiss possibility of the errors in the experiment feedback. 


\section{REFERENCES}

1. Becker, J.B. et al Behavioral Endocrinology. Oxford: MIT Press, 2002:

2. Boldbaatar, G. Neuromarketing. Ulaanbaatar: University of the Humanities Press, 2014.

3. Boldbaatar, G. Marketing research. Ulaanbaatar: University of the Humanities Press, 2015

4. Boldbaatar, G. Consumer behavior. Ulaanbaatar: University of the Humanities Press, 2004

5. Canli, T. (Ed.) Biology of Presonality and Individual differences. New York: Guilford, 2006

6. Dabbs, J.M. Testosterone and Behavior. Columbus: McGraw Hill, 2000

7. Forgas, J.P. Feeling and Thinking. Cambridge: Cambridge University Press, 2000

8. Goldberg, E. The Executive Brain. Oxford: Oxford University Press, 2001

9. Graf, P. Lifespan Development of Human Memory. Cambridge: MIT Press, 2002

10. Grigsby, J. et al. Neurodynamics of Persobality. Greensboro: Guilford, 2000

11. Haan, M. et al. Cognitive Neuroscience of Development. New York: Psychology Press, 2003

12. Hans- Georg Hausel "Brain View", 2008

13. Hausel, H.G. Think Limbic! Planegg: Haufe Verlag, 2002

14. Hausel, H.G. Limbic Success! Planegg: Haufe Verlag, 2003

15. Hellige, J.B. Hemispheric Asymmetry. Harvard: Harvard University Press, 2001

16. Hof, P. et al. Functional Neurobiology of Aging. London: Academic Press, 2001

17. Kahneman, D. et al. Choices, Values and Frames. Cambridge: Cambridge University Press, 2000

18. Kim Min Ju "Neuromarketing", 2008

19. Leon-Carrion, J. Behavioral Neurology in the Elderly. London: CRC-Press, 2001

20. Miller, B.l. et al. The Human Frontal lobes. New York: guilford Publications, 1999

21. Parker, A. et al. The Cognitive neuroscience of Memory. New York: Psychology press, 2002

22. Powell, D. H. Profiles in Cognitive Aging. Harvard: Harvard University press, 1994

23. Raichle, M. E. et al Practice related changes in human brain functional anatomy during nonmotor-learning. p4, 8-26, In: Cerebral Cortex, 1994

24. Roberts, A.C. et al. The Prefrontal Cortex. Oxford: Oxford University Press, 1998

25. Rolls, E.T. The Brain and Emotion. Oxford: Oxford University Press, 1999

26. Whalley, L The Aging Brain. Portland: Weidenffeld\&Nicolson, 2001

27. Zaidel, E. The Parallel Brain. Cambridge: MIT Press, 2003

28. Available from: http://en.wikipedia.org/wiki/Neuromarketing

29. Available from: http://neuromarketing.blogs.com/

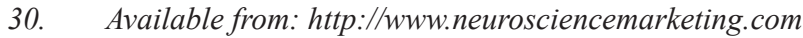

31. Available from: $\mathrm{http}: / / w w w . k y o b o b o o k . c o . k r$ 